\title{
Housing Desegregation in the Era of Deregulation
}

\author{
Christopher Bonastia
}

W

hen Jimmy Carter was sworn into the nation's highest office on January 20, 1977, Civil Rights supporters mustered some hope. In "The State of Black America-1977," the Urban League reflected this tempered optimism:

After eight years of a national Administration that blacks-rightly or wrongly-regarded as hostile to their needs and aspirations, they now feel that 1977 might bring a change in direction and that possibly the same type of moral leadership that led the nation to accept the legitimacy of black demands for equality during the 60 s, might once again be present in Washington. ${ }^{1}$

While 94 percent of Black voters supported Carter, the intensity with which the administration would address issues of racial inequality was unclear. As Hugh Davis Graham notes, Carter "stepped into a policy stream that since the late 1960s had carried two conflicting currents": the "white backlash" politics exemplified by Nixon's "Southern strategy," and "the quiet mobilization of a comprehensive regime of civil rights regulation.... By the mid-1970s, the expanded civil rights coalition, under the adept coordination of the Leadership Conference on Civil Rights, had won bipartisan respect in Congress for its ability to mobilize constituency group support." However, Civil Rights gains tended to come in "complex areas little understood by the general public, such as employee testing and minority hiring tables," rather than in high-profile issues such as housing desegregation. ${ }^{2}$

While housing had ranked high on Carter's list of legislative priorities, his focus was on bolstering construction, home ownership, public housing, and rent subsidies rather than fair-housing issues. ${ }^{3}$ Ironically, fair-housing proponents would have been pleased if HUD's commitment to desegregation under Carter

Christopher Bonastia is a professor of sociology at Lehman College and the City University of New York Graduate Center and the associate director of honors programs at Lehman College. He is the author of Knocking on the Door: The Federal Government's Attempt to Desegregate the Suburbs (Princeton University Press, 2006) and Southern Stalemate: Five Years without Public Education in Prince Edward County, Virginia (University of Chicago Press, 2012).

Kalfou, Volume 1, Issue 2 (Fall 2014). ( 2014 by the Regents of the University of California. ISSN 2151-4712 (print). ISSN 2372-0751 (online). http://dx.doi.org/10.15367/kf.vli2.36. All rights reserved. 
returned to the levels of vigor present during the early part of the Nixon era. In the intervening years, however, courts became more conservative in their rulings on Civil Rights issues, public distrust of the federal government continued to grow, and Congress, with presidential support, worked to shift governmental authority from the national to the state and local levels. Most advocates believed that a reinvigorated fair-housing effort should include opening the suburbs to people of color and low- and moderate-income families, as well as attempts to reverse the precipitous decline of many city neighborhoods. Because the private sector and local governments had proven unwilling to try to alter stratified residential patterns, any meaningful changes would likely require federal muscle. Such activity would run counter to the deregulatory mood that prevailed in the late 1970s, as Congress enacted laws reducing government oversight of the airline, trucking, and communications industries. ${ }^{4}$

This article examines federal housing desegregation efforts during the four presidential administrations-Nixon, Ford, Carter, and Reagan - that held office following passage of the Fair Housing Act in 1968. The presidencies of Richard Nixon and Jimmy Carter receive the closest attention, as hopes for a vigorous fair-housing enforcement effort were highest in these two periods (1969-1974 and 1977-1980). In both periods, the president was unenthusiastic about spending political capital on such controversial efforts, but the secretaries of Housing and Urban Development (HUD) who served them-George Romney and Patricia Roberts Harris-worked to implement policies to encourage racial and economic desegregation in housing. Ultimately, neither was able to gain sufficient traction to do so.

Romney confronted a president who seethed at court- and agency-fueled school desegregation initiatives, not wanting to see the same happen in housing. As HUD Secretary, he found himself in the middle of conflicts among agency staffers responsible for housing production and their "adversaries" in fair housing and equal opportunity. Nevertheless, potential leverage lay in favorable court rulings and large federal commitments to subsidized housing, which could be used to foster desegregation. By the time Patricia Roberts Harris took the helm at HUD, Congress had loosened Civil Rights requirements for receiving federal funding, judges had become markedly less supportive of aggressive desegregation interventions, and officials representing declining cities were demanding that HUD funding be directed to their localities rather than to suburban towns, which typically showed little interest in federal grants that compelled them to foster economic and racial desegregation.

The Reagan administration that followed displayed an unmistakable hostility to governmental intervention in private markets, particularly to enforce Civil Rights, and the president worked with considerable effectiveness to ensure that federal agencies acted in accord with his priorities and preferences. Prior to Reagan, federal agencies often were able to carry out their own agendas with 
remarkable independence from the executive branch. ${ }^{5}$ The Reagan era accelerated the federal withdrawal-now seemingly permanent-from making serious efforts to counteract the residential segregation that the federal government had done so much to help create. ${ }^{6}$

In analyzing this last stab at housing desegregation under Carter, this article examines the housing policies he inherited from Presidents Nixon and Ford. It also addresses executive and congressional reluctance to bolster oversight of the private sector and local government during the Carter years, especially when it came to the thorny issue of fair housing. Federal compulsion to break down the homogeneity of many suburbs would have had steep political costs, given the increasing political power of the suburbs. By 1970, a greater percentage of Americans lived in the suburbs (37.6) than in central cities (31.4) or rural areas (31). In the decade that followed, central cities withstood an out-migration of thirteen million people, mainly to suburban areas. ${ }^{7}$

\section{Fair-Housing Policy under Nixon}

Federal housing desegregation initiatives came mainly through the US Department of Housing and Urban Development (HUD), created in 1965 via the merger of existing housing agencies. Two 1968 laws-the Fair Housing Act (officially, the Civil Rights Act of 1968) and the Housing and Urban Development Act-charged HUD with, respectively, policing housing discrimination and overseeing major increases in housing production. The Fair Housing Act had passed Congress in unlikely fashion due to the confluence of a number of factors, including tactical errors by southern opponents of the bill, softened resistance from the housing industry, legislative compromises proposed by Senate Minority Leader Everett Dirksen (R-IL), the newly released Kerner Report's stark analysis of the racial divide in the nation, and the assassination of Dr. Martin Luther King Jr.

King's death-along with the civil disturbances that erupted subsequentlyhelped to end the stalemate over the bill in the House. As part of the compromise brokered by Dirksen, owner-occupied single-family homes and units with four or fewer units were exempted from coverage. More importantly, enforcement provisions in the 1968 law were markedly weaker than those in the 1966 fairhousing bill that died in the Senate after passing the House. In 1968, Congress passed a law that symbolized its concern with racial segregation and discrimination in housing, but offered federal authorities weak weapons to combat these long-festering problems. Private lawsuits, as difficult as they are to fund and pursue, would become the most powerful means to advance fair-housing law. The Justice Department was authorized to bring "pattern and practice" suits, while HUD could attempt conciliation with parties accused of violating the law. If the accused parties refused, HUD had little recourse. ${ }^{8}$ 
HUD, however, was not completely hamstrung. The law instructed HUD and other federal agencies to "affirmatively" further fair-housing goals; this vague objective was subject to a wide range of interpretation. More concretely, the Housing and Urban Development Act aimed to increase federal housing subsidies more than sixfold, to an average of 600,000 subsidized starts annually between 1969 and 1978. Control over funds for housing subsidies, as well as monies for other programs such as urban renewal and Model Cities, gave HUD the ability to favor applications that would foster economic and racial desegregation. ${ }^{9}$ In this effort to increase the availability of housing for low- and moderateincome families without relying on the construction of unpopular, high-rise public-housing projects, the federal government made a bargain for which HUD would pay dearly, in dollars and credibility, before Nixon left office: it assumed virtually all of the risk in housing subsidization, while the profits accrued to private-sector actors in the housing industry. As explored later in this article, this arrangement led to reckless, crass, and often corrupt behavior by housing developers and real-estate brokers, who sometimes colluded with appraisers at the Federal Housing Administration-one of the formerly independent agencies folded into HUD when the housing agency was created in 1965- to "flip" FHAinsured homes for substantial profits.

At the outset, it was unclear how much leeway President Richard Nixon would permit HUD in pursuing housing desegregation. Nixon's public and private statements made it clear that his political allegiance lay with working whites (the so-called "Silent Majority") who, in his sympathetic view, merely wanted the federal government to leave them alone rather than force their children to attend integrated schools or force businesses to hire less-qualified Blacks. Nevertheless, it was under Nixon that the greatest progress in school desegregation took place, and that affirmative action in employment took root. ${ }^{10}$ Nixon's HUD Secretary, George Romney-a liberal Republican and former governor of Michigan-believed fervently that housing desegregation was a matter of great urgency, even as he vacillated about the methods that the government might employ to bring about this change. The HUD Secretary insisted publicly that "the future of our country depends upon our success in finding more effective solutions to our problems of poverty, race, housing and the cities." He called the confrontation between poor, minority central-city residents and middle- and upper-class people in the segregated suburbs "the most explosive threat to our nation." ${ }^{11}$ Yet Romney realized that conveying the depth and scope of the problem to the American public was an uphill battle: "This problem is as complex and sensitive domestically as Vietnam internationally, and I might add that it has been burdened by the same lack of accurate reporting."'12

Several federal courts found that the federal government had the right-indeed, the obligation — to break down residential segregation in suburbia, largely through withholding federal funds to localities that refused to accept low- and 
moderate-income housing within their borders. For example, in HUD v. Shannon (1970; 436 F.2d 809), the US Court of Appeals (Third Circuit) ruled that HUD's decisions on approving proposed housing projects must consider whether they would perpetuate racial concentration, although the agency could weigh other factors as well. Judge John H. Gibbons wrote: "Increase or maintenance of racial concentration is prima facie likely to lead to urban blight and is thus prima facie at variance with the national housing policy." An internal White House memo highlighted the significance of recent court verdicts on housing:

Under the unanimous and accelerating trend of federal and state decisions HUD's policies are essentially what the courts require. ... The hydraulic principle that was operative in the school desegregation area is now clearly at work in housing - a vacuum of governmental policy in a Fourteenth Amendment area producing energetic "affirmative action" policy on the part of the courts. The judicial surge in the housing area is particularly rapid because of preconditioning of courts and litigants by a decade of civil rights legislation. ${ }^{13}$

In Black Jack, Missouri, an unincorporated area of Saint Louis County, local church organizations secured HUD approval in June 1970 to build a lowincome, federally subsidized housing project. The Black Jack City Council responded by incorporating the town and passing a zoning ordinance to ban the construction of all new multifamily housing, a move that Romney believed was in clear violation of the Constitution and the law. The Justice Department delayed intervening in the case for a year, finally deciding to file suit following an ambiguous statement by Nixon on federal housing policy and pressure from Romney and outside fair-housing supporters. ${ }^{14}$ In the wake of the announcement, Romney and Attorney General John Mitchell suggested that the administration would become involved in housing cases where racially discriminatory intent was clear, but would not, in Romney's words, "assume the role of omnipotent hero righting all wrongs, knocking down all barriers with a flourish and redrawing the crazy-quilt map of our metropolitan areas." For all his desire to break down segregation, Romney acceded to White House demands that he scale back his directives and rhetoric on suburban desegregation if he wished to remain HUD Secretary. ${ }^{15}$

In light of judicial support for fair housing, HUD attempted to convince communities that their agreement to accept a reasonable share of low- and moderate-income housing voluntarily would forestall stringent, court-mandated requirements. Romney predicted that "if the courts start ordering housing dispersal across metropolitan areas, it will provoke a far greater social crisis than the school busing one." He insisted that courts would, nevertheless, demand that these housing opportunities be created if localities did not take it 
upon themselves to do so. "And if that happens," Romney warned, "the local communities will have to suffer the consequences. I can tell you right now that they won't like them. We have been trying to tell communities that. And so has the President."16

As controversies over school desegregation continued, Nixon did not wish to see Civil Rights enforcement in housing travel a similar path. In a move that essentially halted HUD's suburban desegregation initiatives, the president declared a freeze on federal housing funding, citing corruption and abuse in Federal Housing Administration programs utilized mainly in inner cities. Several new programs enacted by Congress in the 1960s led FHA to do business in "risky" locales that it had historically avoided. Section 221(d)(2), an unsubsidized program enacted in 1961, liberalized down-payment rules and lengthened maturities to enable inner-city residents to use the insurance programs. These developments opened a new market for real-estate speculators. Under the National Housing Act of 1968, Congress created the Section 235 program, which subsidized interest payments for homebuyers, and the Section 236 program, which gave similar breaks to cooperative, nonprofit, or limited-profit developers constructing multi-unit rental or cooperative dwellings. As part of the deal, the developers were required to offer a specified number of apartments to lowincome tenants, who would pay rent that did not exceed one-quarter of their income. The 1968 law also established Section 223(e), which created a special risk pool to back high-risk mortgages in areas that were traditionally redlined. These well-intentioned changes created an environment that invited corruption, with unscrupulous individuals chasing quick profits. ${ }^{17}$

The media uncovered collusion between FHA appraisers who inflated their figures, HUD officials who accepted bribes, and real-estate operators and agents who reaped substantial profits. In one Saint Louis neighborhood where crime had skyrocketed, blockbusters purchased twenty-three houses for an average price of \$5,000 each. After making minor, cosmetic repairs, the buyers persuaded FHA appraisers to estimate the houses to be worth $\$ 10,000$ and good for twenty- to thirty-year mortgages. Unsuspecting families bought the homes. By early 1972, all twenty-three houses had been demolished. From January 1968 to June 1971, the agency foreclosed on over 2,800 properties, exceeding the cumulative total for the preceding thirty-three years of FHA activity. HUD was believed to be the largest owner of single-family dwellings in cities such as Detroit and Philadelphia. In the future, Congress would be wary of making large expenditures for low-income housing subsidies. ${ }^{18}$

In January 1973, HUD Secretary Romney outlined an eighteen-month moratorium on housing funds that would take effect for all housing not already approved by HUD. As described by Romney, the housing freeze consisted of the following policies: a moratorium on all new commitments for subsidized housing programs (including Sections 235 and 236); no new commitments for water 
and sewer grants, open-space land programs, or public-facilities loans until Congress established a program of community-development special revenue sharing under which these programs would be subsumed; and a hold (effective July 1, 1973) on all new commitments for urban renewal and Model Cities funding, as well as for smaller Farmer's Home Administration programs in the Agriculture Department. Prior to the moratorium, HUD made no attempt to fix problems in the 235 and 236 programs. The agency did not develop formal justification for the decision until after the freeze was announced, and HUD's rationale was criticized in a departmental memo as "paper-thin, highly subjective, and totally unsupported by any back-up data." ${ }^{19}$ Without the capability to grant or deny funding for subsidized housing or other federal programs, HUD had lost its biggest "stick" to encourage racial and economic desegregation. Suburban desegregation initiatives were a casualty, perhaps an intended one, of the scandals in the mortgage subsidy programs, which did little to alleviate racial and economic segregation. HUD's Civil Rights officials were not involved in the corruption; indeed, they had grown exasperated with the refusal of Federal Housing Administration officials, who administered the programs, to account for Civil Rights concerns in their funding decisions. FHA staffers were concerned with rapid approval of applications-as their success was measured in production numbers-and resented officials elsewhere in HUD who might slow this process. ${ }^{20}$

The move to stop suburban integration initiatives indirectly was classic Nixonian pragmatism. "Little interested in the substance of domestic policy beyond its political repercussions," Hugh Davis Graham writes, Nixon "was free to tailor his policies on civil rights to maximize their political payoff." 21 For example, in supporting the Philadelphia Plan to integrate the construction trades, the Nixon White House believed it had identified a strategy to divide two of the Democratic Party's core constituencies, African Americans and labor. ${ }^{22}$ On the whole, the common thread in Nixon's Civil Rights policies is the desire to avoid blame. A blatant attack on Civil Rights-enforcement initiatives would draw swift criticism from the news media and Civil Rights organizations. A much safer strategy was to shift political responsibility for aggressive enforcement rhetorically to Congress and the courts (as in school desegregation), or to vitiate the enforcement effort indirectly (as in housing). ${ }^{23}$

Continuing tensions over suburban integration and accelerating subsidizedhousing costs were clear incentives for the president to institute the moratorium. During Nixon's first term, housing subsidy outlays increased fivefold, with nearly \$2 billion allocated in the 1973 fiscal year. Meanwhile, federal subsidized-housing starts jumped from 91,400 in 1967 to highs of approximately 430,000 in both 1970 and 1971. By the middle of Nixon's first term, the economy was floundering under ongoing inflation and unemployment, an approaching trade imbalance, and an international monetary crisis. ${ }^{24}$ The scandals in the 
mortgage-subsidy programs offered Nixon the justification for decimating the agency's controversial, expensive efforts to aid private-housing construction and presented him with the opportunity to extirpate desegregation efforts. While Nixon failed to mention desegregation initiatives as either cause or casualty of the freeze, the impact was unmistakable. Revealingly, HUD canceled its plans to promote and observe the fifth anniversary of the Fair Housing Act three months after the freeze. ${ }^{25}$ The Nixon administration's backpedaling from fair-housing issues of suburban desegregation and inner-city revitalization would continue under the Ford and Carter administrations.

\section{Opposing "Black Intrusion"}

Congress passed the Housing and Community Development Act of 1974 under new president Gerald Ford. The legislation created community-development block grants (CDBGs), which allowed communities to receive lump sums from HUD rather than apply separately for individual development programs. While the overriding purpose of the act was to give communities chunks of federal money with few strings attached, the legislation specified that the law's purposes included "the reduction of the isolation of income groups within communities and geographical areas" and "the spatial deconcentration of housing opportunities of persons of lower income." The Ford administration inconsistently applied the provision that the $\$ 4$ billion grant program mainly benefit lowerincome people, leading HUD's Assistant Secretary for Fair Housing and Equal Opportunity to deem enforcement of CDBG guidelines as "lax" and "wholly inadequate." ${ }^{26}$ Indeed, some communities were able to fund tennis courts and golf courses with federal block-grant monies. ${ }^{27}$ The era of heightened federal oversight in housing had not lasted very long.

The Ford administration faced the issue of suburban desegregation head-on in the Supreme Court's Hills v. Gautreaux decision (425 US 284) of April 1976. The Court affirmed that HUD was complicit in promoting segregation in Chicago's public-housing projects, quoting the Appeals Court finding that "HUD retained a large amount of discretion to approve or reject both site selection and tenant assignment procedures of the local housing authority," and that the agency had utilized those powers "in a manner which perpetuated a racially discriminatory housing system in Chicago." The Supreme Court found that

the relevant geographic area for purposes of the respondents' housing options is the Chicago housing market, not the Chicago city limits. That HUD recognizes this reality is evident in its administration of federal housing assistance programs through "housing market areas" encompassing "the geographic area within which all dwelling units . . are in competition with one another as alternatives for the users of housing." ${ }^{28}$ 
HUD Secretary Carla A. Hills, who had appealed the case to the Supreme Court in an attempt to confine the remedy to city limits, told reporters that existing federal incentives for communities to construct low-income housing would likely prove sufficient to increase housing options in the suburbs: "I think most communities do want to address those needs. I think that we aren't going to find a lot of communities shirking their responsibility." ${ }^{29}$ Whether genuine or calculated, Hills's predictions would prove deeply mistaken.

President Ford expressed his views on federal action to encourage economic and racial desegregation with little subtlety, arguing that "an ethnic heritage is a great treasure of this country, and I don't think that Federal action should be used to destroy that ethnic treasure." ${ }^{30}$ As a candidate, Jimmy Carter asserted that as president, he would not "use the Federal Government's authority to deliberately circumvent the natural inclination of people to live in ethnically homogeneous neighborhoods." He went on to speak of "black intrusion" into white neighborhoods, and spoke of the ill effects of "injecting" a "diametrically opposite kind of family" or "a different kind of person" into a neighborhood. After the comments caused a political firestorm, Carter apologized for his "unfortunate choice of words"- specifically a reference to the "ethnic purity" of neighborhoods-but reiterated that he "would not arbitrarily use Federal force to move people of a different ethnic background into a neighborhood just to change its character." ${ }^{31}$ This sentiment reflected Carter's restrictive belief that "government cannot solve our problems. ... It cannot eliminate poverty, or provide a bountiful economy, or reduce inflation, or save our cities, or cure illiteracy, or provide energy." ${ }^{2}$ The president's philosophy dovetailed with political calculations, as he owed his election not only to Blacks and union members but also to young, suburban professionals and "rural Protestants who had no desire to see him embark on expensive social welfare programs for the inner cities." ${ }^{33}$

Despite the legislative push to deregulate several major industries, including banking, Congress had passed the Home Mortgage Disclosure Act (HMDA) in 1975 to address the practice of "redlining," or refusing to make loans available in particular neighborhoods due to race, income, or other demographic factors. This law requires lending institutions in metropolitan areas to list total loans granted by census tract, in order to allow interested groups to monitor the degree to which these institutions reinvest in neighborhoods from which they draw deposits. ${ }^{34}$ Two years later, Congress passed the more rigorous Community Reinvestment Act (CRA). The latter stipulates that regulated financial institutions have "continuing and affirmative obligations to help meet the credit needs of the local communities in which they are chartered," and requires federal bank regulators to "assess the institution's record of meeting the credit needs of its entire community, including low- and moderate-income neighborhoods, consistent with safe and sound operation of such institution," and to "take such record into account in its evaluation of an application for a deposit facility, office 
relocation, merger or holding company acquisition of a depository institution." ${ }^{35}$ The CRA, as "a short title in a long piece of legislation" (the Housing and Community Development Act of 1977), provoked minimal debate on Capitol Hill, as supporters "portrayed the bill as a small clarification to the existing regulatory framework governing the banking industry." The act's lack of funding authorization, specific mandates, or sanctions also likely contributed to its low profile. ${ }^{36}$

Enforcement of these statutes was assigned to the four federal financial regulatory agencies: the Board of Governors of the Federal Reserve System (FRB), the Federal Home Loan Bank Board (FHLBB), the Federal Deposit Insurance Corporation (FDIC) and the Office of the Comptroller of the Currency (COC). ${ }^{37}$ A 1979 US Commission on Civil Rights review found that the four agencies had not "demonstrated sufficient use of [Equal Credit Opportunity Act] data or of the census tract data required by HMDA." As of May 1978, "none of the [four] agencies had ever initiated formal enforcement actions, such as administrative proceedings against a regulatee or referral to the Department of Justice. They have, however, allowed fair housing violations to remain uncorrected." 38

Even had enforcement been more rigorous, the HMDA and the CRA represented a modest step to counteract private-sector disinvestment in declining inner-city neighborhoods. To many observers, such as U.S. News and World Report, the prognosis for saving cities was bleak:

The downward slide of America's cities - and not only the oldest and biggest ones-is accelerating again. All the old problems are still there. Now, recession and nonstop inflation are bringing long-standing woes to a head. Some say to a point of peril. Big-city crime, after a brief leveling off, is once more on a frightening rise. Welfare costs are multiplying in cities such as Detroit, hard hit by unemployment. Detroit is not alone. ${ }^{39}$

The mid-seventies were a tumultuous time; between 1974 and 1977, as the New York Times recalled the period, New York City endured "terrorist bombs exploding in office buildings and department stores; a citywide blackout that led to arson, looting and 3,000 arrests; and a psychopathic killer called Son of Sam, who shot six people dead, wounded seven others and terrorized the city." 40 These events unfolded amid a severe fiscal crisis that elicited little sympathy from Gerald Ford. The president vowed to veto any legislation calling for "a federal bail-out of New York City," prompting the now-legendary New York Daily News headline: "Ford to New York: Drop Dead." Though Ford had never uttered those precise words, the headline was apt, if somewhat sensationalistic (in classic New York tabloid fashion). The president eventually approved $\$ 2.5$ billion in federal loan guarantees, but the city still reeled from the layoffs of 3,400 police officers, 1,000 firefighters, and 4,000 hospital workers. ${ }^{41}$

Cities, it appeared, were dying, and in desperate need of life support; suburbs 
desperately wanted to be left alone. Carter displayed little enthusiasm for sizable federal spending on urban issues. Historian John F. Bauman writes that Carter's "real passion lay not with reinvigorating America's distressed cities ... but with balancing the federal budget." ${ }^{\prime 2}$ Moreover, Carter "inherently distrusted large-scale government programs," which he believed had proven to be failures; "generally opposed increasing federal urban expenditures-a decision rooted in his disapproval of 'special interest' politics and in his fiscal conservatism"; and "believed in the capacity of the private sector (profit and nonprofit) to solve urban problems." ${ }^{43}$ Even had he been more receptive to such a policy initiative, troublesome inflation-and its more sinister cousin, stagflation-and ballooning federal deficits provided formidable disincentives to making large federal investments in cities. The increased oversight prescribed by the anti-redlining laws conflicted with Carter's general inclination towards deregulation; yet it also jibed with his belief that the private sector should take the lead in solving urban problems and, in this case, lending its own money rather than requiring the government to spend public dollars. Moreover, the two laws-one of which was enacted before his election-stemmed from congressional initiative, so Carter incurred no political damage from the regulatory thrust of the laws.

\section{Disenchanted}

It was not long before Black leaders registered their sense of disappointment with President Carter for failing to uphold his campaign promise to aid the inner-city poor. Six months after the inauguration, the Urban League's Vernon Jordan - an old friend of Carter-criticized the president in a speech at the organization's annual convention: "It is not enough to do better than Nixon or Ford. . . Black people, having tasted the sweetness of victory in November [1976], resent the sour taste of disappointment in July [1977]." Carter, who spoke immediately after him, retorted that he had "no apologies to make." This conflict, Newsweek adjudged, "was probably inevitable, given the high-dollar hopes of the black leadership at Carter's election and the balance-the-budget economics he has plied ever since." ${ }^{\text {"4 }}$

Carter's choice for HUD Secretary, Patricia Roberts Harris, became the nation's first Black female Cabinet member, and would prove to be a committed advocate for the housing needs of low-income families and African Americans. Initially, according to the Washington Post, Harris "had been roundly criticized by mayors, urban lobbyists, and others who said she did not have the background to run the troubled housing agency with its staff of about 17,000 and annual budget approaching $\$ 11$ billion." However, she began to "turn many of her doubters into strong supporters. ${ }^{35}$ One of her early critics, US Conference of Mayors Executive Director John Gunther, had changed his mind by mid-1979: "She learned very fast. She appointed very good people under her." ${ }^{\text {"46 }}$ 
Carter and Harris did not always see eye-to-eye on the proper role of the federal government in increasing housing opportunities. At a March 1977 news conference, Carter was asked about Harris's apparent move "towards a policy that would promote racial integration of the suburbs" by withholding federal dollars from neighborhoods that did not comply. Speaking more carefully this time, Carter described his interpretation of current law:

Communities that request Federal help in establishing housing have to put forward a positive proposal to ensure a mixture of housing in the entire community, without regard to race and without regard to the economic level of the families involved. This does not mean that every individual city block or suburban block has to have all different kinds of housing in it. It does mean that the overall package as proposed to the Federal Government has to provide for a wide distribution of housing opportunities for those in minority groups or those who have a low income. ${ }^{47}$

Harris was more blunt: "Communities that say we will take the benefit of a good tax base but will not let people who might benefit from that employment live in that community ought to be required to think about the injustice of that. Where Federal funds are used, they should not be used to undergird injustice." She went on to caution: "Let's not make any assumption that to be black or poor constitutes a problem. The real concern is that these two conditions not be conditions that the Federal Government accepts as a basis for the denial of the right of choice." 48

HUD began putting Harris's words into action, rejecting some block-grant applications from locales with a poor record on low-income housing (such as Hempstead, New York), and approving others (such as Boca Raton, Florida) only after procuring commitments from the communities to provide some low-income housing. Other communities, including Warren, Michigan, stopped applying for the grants. ${ }^{49}$ The agency faced twin pressures to continue using its financial leverage over suburbs while also allocating badly needed funds to central cities. In October 1977, the National Committee against Discrimination in Housing (NCDH) praised the agency's "commendable effort to untangle itself from the worst effects of the Nixon-Ford 'New Federalism' legacy," but contended that "HUD's emphasis upon programs to revitalize the central cities' neighborhoods has not been matched . . by a strategy for metropolitan mobility for lower-income persons, especially racial minorities." If suburban localities widely rejected community development funds requiring provision of low-income housing, as seemed likely, this would "hasten realization by both the Executive and Legislative branches of Federal government that adequate provision for equal opportunity throughout metropolitan areas requires housing programs, which are not dependent upon local governmental approval," the advocacy group rea- 
soned. NCDH observed that the effectiveness of federal programs in central cities "is primarily a matter of money," because "mayors are clamoring for both community development grants and housing assistance." For the suburbs, however, effectiveness was "primarily a matter of administration, legal actions, and politics (assuming, of course, that the necessary units have been allocated)." ${ }^{50}$ Congress and the White House were in no mood to take political and financial hits for crafting an effective and compassionate low-income housing policy.

Even HUD's more limited efforts met with stiff resistance. In October 1977, HUD proposed regulations requiring that at least three-quarters of CDBG funds, which nearly 2,500 localities received in 1975, be used to benefit low- and moderate-income people. Following strenuous objections from suburban localities, influential interest groups and Congress, the final regulations merely stipulated that "all projects and activities must either principally benefit low- and moderate-income persons, or aid in the prevention or elimination of slums and blight, or meet other community development needs having a particular urgency." 51 Under Carter, Bauman writes, "the bulk of CDBG monies went to downtown revitalization, not to distressed neighborhoods... The Carter Administration, strapped by inflation and the energy crisis and politically weakened, quickened the retreat from the problems of the ill housed." Banks and insurance companies poured money into downtown revitalization and gentrifying urban neighborhoods, "prodded and encouraged by HUD and its pallet of CDBG, Section 312 housing rehabilitation loans, tax credits for historic preservation, and other [Federal Housing Administration] and tax incentive programs." ${ }^{52}$

The political difficulties did not end there, as Black politicians serving urban constituencies began to question the wisdom of begging resistant suburban locales to take HUD money when cities needed it desperately. Appearing in June 1977 at the US Conference of Mayors, Harris listened to Detroit Mayor Coleman Young's exasperation with HUD for trying to force suburban Southfield to accept 1,200 units of subsidized housing while 180 acres in the middle of Detroit remained vacant. As a result, he said, no such housing was being constructed in the Detroit area. Six months later, the agency announced a "major policy change," wherein more federal housing money would be directed to central cities by funneling money directly to them, rather than having cities compete for a chunk of the allocation made to the larger metropolitan area of which they were part. At the time, the federal government was spending $\$ 1.1$ billion annually on rent subsidies and public housing combined. ${ }^{53}$ As noted by the New York Times, the shift "comes at a time when many white suburbs are bitterly resisting Federal efforts to compel them to accept such housing. Already this year the department has withheld Federal community development funds from at least 10 towns that have refused to provide enough low-income housing." Localities affected included Hempstead, New York; East Hartford, Connecticut; Millville, New Jersey; and Livonia, Michigan. Fairfax County, Virginia, capitu- 
lated to HUD's demands to allow a subsidized project for one hundred low- and moderate-income families rather than foregoing $\$ 3.7$ million in federal funds. ${ }^{54}$

HUD's constraints on aggressive desegregation efforts were institutional as well as political. Since the passage of the Fair Housing Act, a conflict between fair housing and other programmatic missions had been brewing. A briefing book prepared for Secretary Harris observed that HUD's incorporation of its Civil Rights function attempted to make "equal opportunity requirements inherent in programmatic requirements, thus providing the same sanctions for deficiencies in equal opportunity as for deficiencies in any other area." While HUD's approach did, in theory, integrate "equal opportunity into all HUD program initiatives," a major disadvantage was that

program staff are often proprietary about the programs for which they are held accountable and jealously guard their prerogative to make the final recommendation or decisions. [The Office of Fair Housing and Equal Opportunity] is looked upon ... as an interloper and a nuisance. FHEO, then, very often is called upon to defend the need and indeed the right to "interfere" in the program process. ${ }^{55}$

A February 1978 report to Congress by the Comptroller General found a wide range of shortcomings in HUD's (and other agencies') enforcement of fairhousing laws covered by Title VI of the Civil Rights Act of 1964, which prohibits discrimination by beneficiaries of federal assistance, and Title VIII of the 1968 Fair Housing Act, which prohibits discrimination in most private- and publicsector housing. The report pays particular attention to HUD's compliance reviews of public housing projects, Section 236 housing and Section 8 housing under Title VI, and the agency's handling of complaints under Title VIII. With regard to the former, the Comptroller examined compliance reviews in three regions (Atlanta, Chicago, and San Francisco) from January 1973 to April 1976, finding that 84 of 1,397 public housing projects (6 percent), 2 of 2,288 Section 236 recipients, and none of the 207 Section 8 recipients were subjected to HUD review. A similarly bleak picture emerged in resolution of Title VIII complaints. During the same period as above, the Comptroller reviewed 332 complaints received in the three regions. In 247 cases (74 percent), HUD could not resolve the complaints due to lack of clear evidence. Of the 57 cases where the agency determined that a discriminatory act had taken place, 36 were resolved.

The Comptroller General identified several factors that contributed to the low percentage of resolved complaints: untimely investigation of complaints; the requirement that HUD defer to substantially equivalent state and local governmental organizations; the failure to investigate complaints by comparing the experiences of Black and white housing "testers"; and the lack of agency authority to resolve complaints. HUD's response to the draft report pinned most 
of the blame for its shortcomings on insufficient staffing (noting that Title VIII complaints increased threefold from 1970 to 1975 with "no commensurate increase in staff") and "less than ardent commitment to fair housing enforcement of prior administrations." ${ }^{.56}$ Tellingly, HUD announced in the autumn of 1977 that the agency would be reorganized for the twentieth time since $1969 .{ }^{57}$

HUD also received continued criticism from politicians representing Black, urban constituencies. In 1980, Rep. William Clay (D-MO), who represented distressed North Saint Louis, said HUD's policy of trying to get suburban towns to build low-income housing was "stupid and asinine," since it gave all the housing money "to St. Louis County where you have a recalcitrant, racist administration opposed to building housing for black people." Instead, Clay suggested, HUD should allocate funds to depressed inner-city areas that actually wanted low-income housing. This stance was partially political, as House members representing districts with declining populations might find the safety of their seats jeopardized. "The only power base that black people have is politics," Clay contended. "And if we disperse that power base before we totally integrate into other power bases, we're damn fools." HUD Secretary Moon Landrieu, who had taken over in September 1979 after Carter appointed Harris to head the much larger Department of Health, Education, and Welfare, signaled the administration's retreat from its suburban integration efforts. He contrasted the suburban integration strategy to the congressional ban against discrimination in public accommodations: "What we didn't do in that process [with public accommodations], that we're doing in housing, is say, 'Here's 50 bucks, go to the best restaurant in town and eat."'58 That is, people should have decent housing, but not necessarily in their preferred location.

One last glimmer of hope lay in the prospects for Fair Housing Act amendments that would enhance HUD's enforcement authority. The White House, Department of Justice, and HUD expressed their support for a bill sponsored by Rep. Don Edwards (D-CA) to strengthen the fair-housing enforcement apparatus by vesting enforcement authority in HUD-appointed administrative-law judges, who could order violators to stop discriminating, impose fines of up to $\$ 10,000$, and order compensation to the complainants. Carter's January 1980 State of the Union Address included the assertion that the fair-housing bill was "the most critical civil rights legislation before the Congress in years," but it was not until April-when the bill was sent to the House floor-that Carter's senior staffers began to lobby intensively for passage. ${ }^{59}$ The bill passed the House before dying in the Senate.

Carter's reluctance to spend his scant political capital to push for suburban desegregation or invest in distressed inner-city neighborhoods gave way to President Reagan's outright antipathy towards such efforts. Beginning in 1983, however, Reagan did voice his support for fair-housing amendments in order to forestall more far-reaching congressional action and avoid criticism of his administration as anti-Civil Rights. ${ }^{60}$ Congress passed the Fair Housing Amendments Act five 
years later under Reagan, who asserted that enactment of the law had brought the United States a "step closer to realizing Martin Luther King's dream." Reagan used the signing ceremony to bolster the Civil Rights credentials of the Republican Party-particularly Vice President George Bush, who would face Michael Dukakis in the presidential election six weeks later. "The Civil Rights Act of 1968 included, for the first time in our history, a fair housing provision," Reagan remarked. "That was a major achievement, one that many members of Congress, including a young Congressman named George Bush, had to show enormous courage to vote for." The president neglected to mention his own record as an opponent of the 1968 Fair Housing Act and of California's fair-housing legislation. ${ }^{61}$

The 1988 amendments were a needed strengthening of the original legislation, which one housing consultant compared to "a no-parking zone with a $\$ 2$ ticket. I don't know anybody who would hesitate to park under those circumstances." ${ }^{2}$ Among other provisions, the amendments permitted discrimination complaints to be filed up to two years after the alleged occurrence (as opposed to three months); created a streamlined hearing process for trying cases before administrative-law judges, who were authorized to order full compensation for damages in addition to civil fines of up to $\$ 10,000$ for the first offense and $\$ 50,000$ for the third offense; authorized the attorney general to seek penalties of up to $\$ 50,000$ for a first conviction and $\$ 100,000$ for subsequent convictions in "pattern and practice" cases; and subjected HUD investigations and complaint resolutions to strict time limits.

Congress gave HUD secretaries the authority to begin investigations in the absence of private suits and file complaints with the attorney general, who was required to act promptly. The attorney general was also empowered to file civil actions for breaches of conciliation agreements and to prosecute cases when defendants chose to try their cases in federal district court rather than before an administrative-law judge. Families with children and disabled individuals were added as protected classes under fair-housing law. While the amendments represented a clear step forward, the law mainly benefited individual victims, rather than helping to uncover and address systemic patterns of discrimination. ${ }^{63}$ Consequently, structural lawsuits remained a key element in the fight for fair housing. As described by Seng and Caruso, "the structural lawsuit utilized injunctions to reform institutions so that they would not discriminate or otherwise violate civil rights in the future. The focus was thus on prospective relief and not on retroactive relief in the nature of damages." ${ }^{\prime 4}$ Successful structural lawsuits were pursued against localities including Black Jack, Missouri (1974); Arlington Heights, Illinois (1977); Chicago (1982, in the Gautreaux case); and Zanesville, Ohio (2008).

Seng and Caruso surmise that the number of these suits has been limited due to an insufficient number of fair-housing actions nationwide, the difficulty of pursuing successful suits with far-reaching remedies against individual 
housing providers, condominium boards, homeowners' associations, and the like, and a more conservative turn by the judiciary. ${ }^{65}$ Consequently, while litigation by fair-housing and other pro-integration groups has proven important in penalizing some of the most egregious violations of antidiscrimination laws, private action has not proven to be an adequate substitute for committed governmental enforcement.

In Washington, neither Reagan nor Congress saw fit to raise the politically explosive issue of suburban segregation. For example, the 1982 Report of the President's Commission on Housing, stretching over three hundred pages, devotes fewer than two pages of mostly boilerplate language to issues of segregation and housing mobility. ${ }^{66}$ With respect to funding, Congress was able to alleviate some of the draconian housing cuts that Reagan pursued; nevertheless, housing allocations from the 1983-1985 fiscal years "represented a reduction in budget authority from pre-Reagan levels of over two-thirds." ${ }^{.67}$ During the 1980s, as funding dwindled, Congress dramatically expanded the number of HUDadministered programs, from fifty-four in 1980 to over two hundred in 1992, increasing the agency's propensity for inefficiency and corruption. The scope of fair-housing enforcement has similarly expanded, as fewer than half of fair-housing complaints filed with HUD involve alleged racial discrimination. (Handicap and familial status are the next most common sources of alleged discrimination after race. $)^{68}$ In 1994, a National Academy of Public Administration study commissioned by Congress recommended that if HUD did not sharply improve its accountability and effectiveness in five years, "the president and Congress should seriously consider dismantling [it] and moving its core programs elsewhere." ${ }^{69}$

Ironically, further deregulation of the banking industry under Reagan gave greater leverage to community groups pursuing the aims of the anti-redlining laws. As the Wall Street Journal explained in 1985, HMDA and CRA "have become potent only with deregulation. As banks try to enter new markets, they need regulatory approval. Using these laws, a savvy activist can threaten to gum up the works unless the bank improves its local-lending performance." Gale Cincotta, a neighborhood activist since the 1960s, headed the Chicago-based National People's Action, an umbrella group representing more than three hundred community groups throughout the United States that had pushed successfully for the passage of HMDA and CRA. "Banking deregulation creates all kinds of opportunities," she said with a laugh in a 1985 interview..$^{70}$ By the following year, the Chicago Reinvestment Alliance had negotiated \$153 million in loan commitments from three of the city's biggest banks. Two of them were trying to buy other banks, while the third was trying to create a Florida holding company. To do so, the banks needed federal approval. Community groups earlier had pressured federal regulators to enforce the redlining laws more forcefully, with little success; the first federal denial of lender action on CRA grounds did not take place until 1989.71 After bank deregulation, the community groups 
began to pressure lending institutions directly, resulting in inner-city loan commitments of at least \$350 million over a two-year period from 1984 to 1986.

These successes were not enough to compensate for the shriveling of federal assistance to city neighborhoods. "The supply of funds made available thus far is nowhere near what's needed to completely rejuvenate our city neighborhoods, especially now that most of the sources of federal assistance to arrest neighborhood decay have been reduced or eliminated," Cincotta observed. ${ }^{72}$ Moreover, it was often the case that

the most credit-worthy projects [such as renovating apartment buildings and single-family homes] are usually ones that do the least to rebuild neighborhoods. And the ones that could offer the most improvementrehabilitating the half-vacant, crime-ridden hulks that discourage nearby homeowners from keeping up their property-are toughest to finance. ${ }^{73}$

Suburban localities had few concerns that the federal government would resume its push for economic and racial desegregation under Reagan. In August 1981, Congress made it easier for localities to receive community-development block grants without building low-income housing by no longer requiring towns with populations under 50,000 to devise a housing plan, allowing cities to consider population declines as well as increases in establishing housing needs, and permitting cities to consider vacancies in neighboring towns when designing their plans. The law "has really been gutted," surmised Raymond J. Struyk, director of the Urban Institute's center for housing and community-development research. ${ }^{74}$

As depicted in Table 1, a critical mass of political support for aggressive housing desegregation initiatives never materialized in Washington during the two decades that followed passage of the 1968 Fair Housing Act.

Table 1. Federal Action Pertaining to Housing Desegregation from Nixon to Reagan

\begin{tabular}{|l|l|l|l|l|}
\hline & $\begin{array}{l}\text { Presidential } \\
\text { Support for } \\
\text { Pousing } \\
\text { Pesegregation }\end{array}$ & $\begin{array}{l}\text { HUD Prioriti- } \\
\text { zation of } \\
\text { Desegregation }\end{array}$ & $\begin{array}{l}\text { Federal Invest- } \\
\text { ment in Urban } \\
\text { Revitalization }\end{array}$ & $\begin{array}{l}\text { Support for } \\
\text { Housing } \\
\text { Desegregation }\end{array}$ \\
\hline Nixon & Very low & $\begin{array}{l}\text { Initially high, } \\
\text { then moderate }\end{array}$ & $\begin{array}{l}\text { High, then very } \\
\text { low (housing } \\
\text { freeze) }\end{array}$ & \\
\hline Ford & Very low & Low & Very low & Low \\
\hline Carter & $\begin{array}{l}\text { Low to } \\
\text { moderate }\end{array}$ & $\begin{array}{l}\text { Initially high, } \\
\text { then moderate }\end{array}$ & Low & Low \\
\hline Reagan & Very low & Very low & Very low & Moderate* \\
\hline
\end{tabular}

* Congress enacted a needed strengthening of the Fair Housing Act, but still displayed little desire to intervene in residential patterns. 


\section{After Reagan}

The first Bush administration, taking office as the fair-housing amendments began to take effect, saw the number of fair-housing complaints double from 4,422 during the final year of the Reagan presidency to 9,320 three years later. Meanwhile, HUD conciliations rose nearly tenfold. HUD Secretary Jack Kemp brought enthusiasm and commitment to his post, but focused almost exclusively on subsidized housing in inner cities, declining to grapple with the hot-button issue of desegregating the suburbs. ${ }^{75}$

President Clinton's first HUD secretary, Henry Cisneros, spoke more boldly about the need to tackle housing segregation, calling racism "the great Achilles' heel of our nation's future" and speaking of his plans to make subsidized housing more prevalent in white suburbs, rather than central cities. "I'm not naïve about how difficult this is," he remarked. "Suburban settings don't want to accept public housing." 76 The Clinton administration broke from the traditional HUD strategy of contesting lawsuits that alleged discrimination in public housing. Instead, it acknowledged the agency's culpability in ignoring segregation and discrimination by local housing authorities, and "developed a strategy of settling the cases by supporting solutions to ensure 'fair housing' for the plaintiffs." ${ }^{\prime 7}$ HUD also implemented the "Moving to Opportunity" demonstration project, which sought to gauge the effects of very low-income public-housing residents moving to low-poverty neighborhoods. Reflecting the delicate politics of the experiment, Congress canceled its second wave of program support-a $\$ 150$ million allocation-after the first congressional allocation of $\$ 70$ million in 1993. Initial plans to assist 5,000 families over a three-year period were attenuated to a one-year demonstration assisting around 285 families in each of five cities (Baltimore, Boston, Chicago, Los Angeles and New York). President Clinton's call in 1998 for legislation to change public housing in order to deconcentrate poverty and increase income and racial integration was never enacted. ${ }^{78}$

Even with the Clinton administration's renewed attention to economic and racial segregation in housing, HUD made no pretenses of thoroughly reshaping housing patterns. Its 1997 Strategic Plan set the modest goal of reducing racial and ethnic segregation in public and federally assisted housing by 5 percent over five years in 50 percent of "selected localities." Under President George W. Bush, HUD's 2006 Strategic Plan for the 2006-2011 fiscal years set no such goals. ${ }^{79}$

Since the early 1990s, federally assisted housing has de-emphasized traditional, "bricks and mortar" public housing. This trend is spurred by the HOPE VI program, introduced in 1993, which furnishes funds to "demolish severely distressed projects and replace them with mixed-income developments." ${ }^{80}$ The national public-housing stock declined by about 140,000 units-from 1.33 million to 1.19 million assisted households-from 1995 to 2007. The largest growth has come in Low Income Housing Tax Credits (LIHTC), which provide sub- 
sidies upfront to developers of rental housing in exchange for their agreement to charge below-market rents. Between 1995 and 2007, LIHTC developments more than tripled, from roughly 430,000 to 1.53 million assisted households. A related "place-based" program, contracting with for-profit and nonprofit housing developers to provide subsidized housing for specified periods of time up to thirty years, shrunk from 1.72 million assisted households in 1993 to 1.29 million fourteen years later; much of this attrition came from developers who declined to renew their contracts with the federal government. Voucher-based assistance has also increased markedly, from 1.2 million assisted households in 1993 to 1.97 million in 2007. Because this is the sole program that is not placebased-recipients can use their subsidies to find dwellings on the open market-it offers some potential for spurring economic and racial deconcentration. (However, families sometimes encounter red tape when attempting to move to a neighborhood covered by a different public housing authority than the one in which they received their voucher.) Indeed, while half of public housing residents live in high-poverty neighborhoods (poverty rate above 30 percent), only 15 percent of voucher recipients do. ${ }^{81}$ As such, tenant-based programs-particularly those that provide counseling to tenants about the full range of housing options-offer a flicker of possibility. ${ }^{82}$

\section{Is Deregulation "Raceless"?}

While the voucher programs mentioned above do seem useful for their recipients, they are not designed to provoke widespread shifts in segregated living patterns. Indeed, vouchers fit neatly into the post-regulatory environment of providing expanded choice for some individuals (in education as well as housing) without addressing broader structural inequalities related to race and income.

One might question whether deregulation was part of a conscious effort by political elites to limit or even reverse the gains of the Civil Rights Revolution. Were deregulation and the contraction of federal ambition connected to anti-Black and anti-poor sentiment? If the federal government had coupled disinvestment in inner cities with an aggressive effort to desegregate the suburbs, one might contend that this was merely a shift in philosophy about how best to help the nonwhite poor. This obviously was not the case, suggesting that federal neglect of cities reflected, at best, apathy toward improving the lives of residents or providing them with plausible options to relocate to a better living situation.

Exploring possible connections between the seemingly distinct policy areas of Civil Rights enforcement, deregulation, federal investment in cities, and crime policy may illuminate changing political conceptions about what, if anything, should be done to aid poor, urban communities of color. Senate debates over the Civil Rights Act of 1968 offer some clues to the anticipated effects of fair-housing legislation on these communities. As Mara Sidney has explained, 
supporters of the legislation argued that the law would not instigate large-scale changes in residential living patterns, but would offer the Black middle class, and some aspiring lower-income Blacks, the chance to expand their residential options. The proliferation of civil disturbances during this period was evoked by supporters and opponents alike. To supporters, a new fair-housing law would affirm to Blacks that they could rely on the government to provide opportunity and fair treatment, while opponents claimed that such a law would reward Blacks for law-breaking and violence. Some opponents also warned that HUD enforcement of the proposed law would trample upon state and individual rights, and that the HUD bureaucracy would seek to expand its power. ${ }^{83}$

As Weaver argues persuasively, opponents of Civil Rights linked activism to crime in an effort to erase the legitimacy of Civil Rights claims:

First, conservatives attached civil rights to lawlessness by arguing that civil disobedience flouted laws and would inevitably lead to more lawless behavior. Thus, nonviolent protest was connected to riots. But then, through a reverse claim, they disconnected the relationship they had just sewn, by arguing that riots were not connected to legitimate grievances but to "crime in the streets." 84

Through such strategies, "racial disorder-initially defined as a problem of minority disenfranchisement-was redefined as a crime problem, which helped shift debate from social reform to punishment." In effect, "crime became an excuse for not expanding civil rights and social justice." ${ }^{85}$ From this perspective, correcting the behavior of the poor, rather than providing them with greater opportunity, was the appropriate focus for government action; harsher criminal penalties would provide incentives to "play by the rules." In his 1968 campaign, Richard Nixon repeatedly stressed the need for law and order, arguing that doubling criminal convictions would do more to decrease crime than quadrupling Johnson's War on Poverty. ${ }^{86}$ This policy thrust did not stop with Nixon. While Carter did not emphasize crime in his statements as candidate and president, he seemingly shared Nixon's philosophy that large government programs could do little to help the poor, and might well hurt them (not to mention the federal budget).

Hostility toward the federal bureaucracy had a racial undercurrent as well. The drive to weaken the power of the federal government and prevent it from "social engineering" began to gain steam in the early 1970s, as the conflict in Vietnam dragged on and resistance to aggressive Civil Rights enforcement intensified when school desegregation reached beyond the South. In his 1968 and 1972 presidential campaigns, George Wallace directed his ire at federal bureaucrats for their ineptitude, their insensitivity, and their interference with matters that were, in his view, none of their business. This was a clever way of attacking programs that ostensibly favored Blacks without resorting to explicitly racist 
appeals. Wallace excoriated "the hypocrites who send your kids half-way across town while they have their chauffeurs drop their children off at private schools." He delighted in taunting the "thousands of bureaucrats toting briefcases in Washington who don't know why they're there. . . I'll bet if you opened half of their briefcases all you'd find would be a peanut butter and jelly sandwich." Nixon also attempted to scapegoat bureaucrats, but this tactic proved more difficult to pursue successfully since he was the reputed boss of federal bureaucrats. Ronald Reagan later used this attack against big government with cynical effectiveness by spinning apocryphal tales of "welfare queens" living leisurely lives on taxpayer tabs. Ultimately, the Nixon administration's entanglement in the Watergate scandal did more to decrease public trust in government than any attacks against "overreaching" bureaucrats. ${ }^{87}$

Denigrating the capability of the federal bureaucracy offered justification for deregulation. Arguing that crime, rather than a lack of opportunity or resources, was what plagued poor neighborhoods led to the conclusion that the federal government could do little to help inner-city residents, other than (supposedly) protect them from the criminals in their midst. In essence, the private sector was freed from regulation while the behavior of poor individuals became hyper-regulated. My claim that the push to shrink Civil Rights enforcement has ties to the turn toward deregulation and punitive crime policies is not to argue that race is the sole driving force behind these two policy paths. I do not suggest that any political actor who supported deregulation of the trucking industry, or who felt that government should address increasing crime rates, harbored racial motives. But it is surely no coincidence that many of the same politicians who opposed Civil Rights legislation and the social and economic advancements of African Americans also attacked federal bureaucrats and called for the government to "get tough" on crime. ${ }^{88}$ Virtually no contemporary politicians publicly repudiate the right of individuals to ascend as high as their talents will take them, free from active discrimination. Yet the support for harsh (and often racially discriminatory) crime policies and timid Civil Rights enforcement fits neatly into the worldview that the United States is now post-racial, despite persistent evidence of continued racial inequality. In this view, race no longer matters, so any differential outcomes by race can be pinned on the moral failings of individuals or the cultural shortcomings of Blacks and Latinos. To accept this dubious assertion is to absolve the government of responsibility to increase opportunity, pursue vigorous Civil Rights enforcement, or invest in the poor.

\section{Discussion and Conclusion}

In the 1970s, shortly after passage of the Fair Housing Act, the federal government began its retreat from housing desegregation, despite the efforts of HUD Secretaries George Romney (under Nixon) and Patricia Roberts Harris (under 
Carter). In the end, neither was able to clear the formidable political and institutional hurdles they faced in such a monumental undertaking. Romney had to contend with a White House that had no interest in compounding the controversies regarding school desegregation with related battles over integrated housing. HUD's halting momentum in suburban desegregation was stopped emphatically when Nixon declared a housing freeze in early 1973 . While federal courts were largely in accord with an expansive interpretation of HUD's fair-housing responsibilities, Congress largely relegated itself to spectator status. Had Congress felt compelled to intervene in housing desegregation issues, it is likely that most members would have sided with Nixon in attempting to curb, rather than enable, suburban desegregation initiatives. Carter faced an even more resistant Congress, especially when it came to Civil Rights enforcement; nominal rights to nondiscrimination had become entrenched, but the desire to enforce those rights vigorously or to offer opportunities to victims of structural inequality had shrunken further.

By the Carter presidency, courts had become less sympathetic to expansive Civil Rights regulation. Nixon's four Supreme Court appointees led this more conservative turn. Even the celebrated Hills v. Gautreaux decision, decided when Ford was president, was narrower in scope than it appears on the surface. Though the remedy for discrimination by the Chicago Housing Authority included placing some of the city's public-housing residents (or prospective residents) in Section 8 housing outside the city limits, the Court specified that suburban localities retained the right to reject Section 8 housing within their boundaries. ${ }^{89}$ While structural lawsuits have produced real benefits for victims of injustice, there is scant evidence to suggest that private enforcement could become the driving force behind widespread housing desegregation.

After early attempts at exerting pressure on suburban localities, the Carter administration-like the Nixon and Ford administrations before it-declined to twist the perfectly tanned arms of suburban localities. The threat to withhold housing funding from suburbs had become an idle one, except perhaps for inner-ring suburbs that were undergoing many of the same problems as their city brethren. These were not the suburbs in which most middle-class families, regardless of race, aspired to live. Affluent suburbs were largely unwilling to take federal money if it meant that they would have to construct housing for low- and moderate-income families. If the federal government had been willing to withdraw all federal funds from uncooperative localities-rather than just discretionary housing funds-some real headway might have been made. ${ }^{90}$

HUD Assistant Secretary Robert C. Embry Jr., who headed the block-grant program under Carter, had raised the possibility of making other grants in areas such as highways, FHA financing, and environmental programs conditional on the acceptance of housing for the poor. He also suggested that HUD might attempt to bypass suburban governments by allocating money to central cities, 
which would finance nonprofit organizations that would buy or construct lowincome housing in the suburbs to house poor city residents. Then, Embry reasoned, the suburban jurisdictions might conclude: "Well, if it's going to happen anyway, we might as well do it ourselves" and receive federal funds directly. ${ }^{91}$ The legality of such action was a matter of dispute, but the political calculustremendous political costs for powerful constituencies, with benefits flowing to the politically marginalized-was crystal clear. Carter's political capital declined rapidly during his years in office, and there is no evidence to suggest that he considered spending it in this area. Personally, Carter may have been more sympathetic to the aspirations of African Americans than was Nixon, but the political price for supporting vigorous Civil Rights enforcement had increased, and Carter was unwilling to pay it.

The increased scrutiny of lenders in declining urban areas stemmed from congressional initiatives; Carter said virtually nothing, pro or con, about HMDA and the Community Reinvestment Act. The latter law in particular jibed with Carter's preference for encouraging private investment in cities, rather than infusions of public funds. Deregulation and federal withdrawal from cities was part of a larger resistance by the White House, Congress, and the public to intervene in the housing market to pursue social goals. Conveniently ignored was the federal government's historical role in nurturing racial and economic isolation in American neighborhoods. ${ }^{92}$

In the 1970s and 1980s, as now, the missing ingredients in addressing residential isolation were HUD's weakness and an absence of political will in Washington. Political actors do not merely react to public sentiment. As Weaver illustrates, conservative entrepreneurs did not shift their focus to crime in response to public outcries; they did so to reframe the issue of racial inequality as one of individual behavior, rather than structural impediments..$^{93}$ While the current political climate makes it unlikely in the short term that entrepreneurs could instigate a sustained federal attack on housing segregation, they might take a useful first step in restructuring the institutional home for fair-housing enforcement within the federal government.

A number of observers of fair-housing enforcement-including former high-level HUD staffers, the Leadership Conference on Civil Rights, National Fair Housing Alliance president and CEO Shanna L. Smith, and me-have argued that fair-housing enforcement should be removed from HUD and assigned to an independent agency. As Smith observes, "Fair housing has never been a priority at HUD. HUD has too many conflicts of interest to be able to effectively enforce the law." ${ }^{94}$ Congress could plausibly take this incremental, but significant first step without much public notice, as agency reorganization typically flies under the radar of voters. In order for such an agency to avoid replicating the weaknesses of its predecessors in HUD, substantial grassroots pressure would be essential. 
A more thoroughgoing push for economic and racial desegregation of housing, especially in suburban jurisdictions, would require severe political courage-clearly, this is not a savory issue for elected officials. Real progress in this area would likely come through a "fair share" arrangement with teeth. Unless all (or nearly all) localities in a given metropolitan area are required to take their "fair share" of low- and moderate-income housing on a nondiscriminatory basis, the prospects for success are bleak. Plotting out a strategy to build the national political will to address economic and racial segregation in housing is, at this point, an exercise in conjecture, perhaps bolstered with a dose of blind hope. In doing so, we would do well to study past failures in national policymaking, as well as grassroots fair-housing efforts that have produced some measurable success.

\section{NOTES}

1. Urban League, “The State of Black America-1977," Staff Office Files: Records of Martha (Bunny) Mitchell, Box 19, Folder: National Urban League, Jimmy Carter Presidential Library (JC), Atlanta, GA.

2. Hugh Davis Graham, "Civil Rights Policy in the Carter Presidency," in The Carter Presidency: Policy Choices in the Post-New Deal Era, ed. Gary M. Fink and Hugh Davis Graham (Lawrence: University Press of Kansas, 1998), 202-203.

3. Ibid., 203.

4. James T. Patterson, Restless Giant: The United States from Watergate to Bush v. Gore (New York: Oxford University Press, 2005).

5. Richard P. Nathan, The Administrative Presidency (New York: Wiley, 1983); Robert Durant, The Administrative Presidency Revisited: Public Lands, the BLM, and the Reagan Revolution (Albany: State University of New York Press, 1992); Dan B. Wood and Richard W. Waterman, "The Dynamics of Political Control of the Bureaucracy," American Political Science Review 85, no. 3 (1991): 801-828; Marissa Martino Golden, What Motivates Bureaucrats? Politics and Administration during the Reagan Years (New York: Columbia University Press, 2000).

6. See Christopher Bonastia, Knocking on the Door: The Federal Government's Attempt to Desegregate the Suburbs (Princeton, NJ: Princeton University Press, 2006); Douglas S. Massey and Nancy A. Denton, American Apartheid: Segregation and the Making of the Underclass (Cambridge, MA: Harvard University Press, 1993); Kenneth T. Jackson, Crabgrass Frontier: The Suburbanization of the United States (New York: Oxford University Press, 1985).

7. Robert Fishman, Bourgeois Utopias: The Rise and Fall of Suburbia (New York: Basic Books, 1987).

8. On passage of the Fair Housing Act, see Mara S. Sidney, Unfair Housing: How National Policy Shapes Community Action (Lawrence: University Press of Kansas, 2003); Charles M. Lamb, Housing Segregation in Suburban America since 1960 (New York: Cambridge University Press, 2005); Charles McC. Mathias Jr. and Marion Morris, "Fair Housing Legislation: Not an Easy Row to Hoe," Cityscape 4, no. 3 (1999): 21-33; Congressional Quarterly, "Open-Housing Law Credited to Mitchell's Lobbying," April 24, 1968, 1-4. On the importance of private lawsuits in the enforcement of fair-housing law, see Michael P. Seng and F. Willis Caruso, "Achieving Integration through Private Litigation," in The Integration Debate: Competing Futures for American Cities, ed. Chester Hartman and Gregory D. Squires (New York: Routledge, 2009), 53-66.

9. William Lilley III, "Housing Report/Administration and Congress Follow Courts in Promoting Residential Integration," National Journal, November 12, 1971, 2431-2439.

10. Bonastia, Knocking on the Door; Dean J. Kotlowski, Nixon's Civil Rights: Politics, Principle, and Policy (Cambridge, MA: Harvard University Press, 2001). 
11. HUD press release, Leadership Conference on Civil Rights (LCCR) Papers, Part I, Box 106, Folder: 1971-1972, February 22, 1972, Library of Congress (LC), Washington, DC; Romney speech to National Association of Home Builders, LCCR Papers, Part I, Box 105, Folder: HUD 1970, January 19, 1970, LC.

12. A. James Reichley, "George Romney Is Running Hard at HUD," Fortune, December 1970, 134.

13. Memo, Leonard Garment to John Ehrlichman, Reel 20, Box 19, 836-45, February 26, 1971, Civil Rights during the Nixon Administration [microfilm] (Frederick, MD: University Publications of America, 1989).

14. United States v. City of Black Jack, 508 F.2d 1179 (8th Cir. 1974, cert. denied, 422 US 1042, 1975).

15. "Nixon's Actions Cheer Fair Housing Backers," Los Angeles Times, June 16, 1971; Bonastia, Knocking on the Door.

16. William Lilley III, "Housing Report/Courts Lead Revolutionary Trend toward Desegregation of Residential Areas," National Journal, November 27, 1971, 2348.

17. Bonastia, Knocking on the Door.

18. William Lilley III and Timothy B. Clark, "Urban Report/Federal Programs Spur Abandonment of Housing in Major Cities," National Journal, January 1, 1972, 26-33; Brian D. Boyer, "HUD Scandal Profited All But Taxpayer," Detroit Free Press, March 19, 1972; Brian D. Boyer, Cities Destroyed for Cash: The FHA Scandal at HUD (Chicago: Follett Publishing, 1973); George R. Metcalf, Fair Housing Comes of Age (New York: Greenwood, 1988); St. Louis Globe-Democrat, "St. Louis' Housing Debacle," March 11-12, 1972.

19. Remarks by Romney to National Association of Home Builders, George Romney Papers, Box 41, Folder: NAHB Houston, January 8, 1973, Bentley Historical Library, Ann Arbor, MI; R. Allen Hays, The Federal Government and Urban Housing, 2nd ed. (Albany: State University of New York Press, 1995); Susanna McBee, "Subsidized Housing Frozen before Justification by HUD," Washington Post, December 3, 1973, A1.

20. US Commission on Civil Rights, "Federal Civil Rights Enforcement: One Year Later," Washington, DC: US Government Printing Office; US Department of Housing and Urban Development, Housing in the Seventies (Washington, DC: US Government Printing Office, 1973); Bonastia, Knocking on the Door.

21. Hugh Davis Graham, The Civil Rights Era: Origins and Development of National Policy, 1960-1972 (New York: Oxford University Press, 2000), 302.

22. John Ehrlichman, Witness to Power: The Nixon Years (New York: Pocket Books, 1982).

23. Chris Bonastia, "Hedging His Bets: Why Nixon Killed HUD's Desegregation Efforts," Social Science History 28, no. 1 (2004): 19-52. On attacks by the media on anti-Civil Rights actions, see Nathan Glazer, Affirmative Discrimination (New York: Basic Books, 1987).

24. On the increase in subsidized housing, see HUD, Housing in the Seventies. On the declining economy, see Stephen E. Ambrose, Nixon: The Triumph of a Politician 1962-1972 (New York: Simon and Schuster, 1989), 457.

25. Telegram, NAACP to James Lynn (HUD Secretary), March 20, 1973, NAACP Papers, VI: F11, HUD 1973, LC.

26. Lamb, Housing Segregation in Suburban America since 1960, 168-169.

27. William Chapman, "HUD Tying Funds for Communities to Subsidize Housing," Washington Post, June 20, 1977, A1; "No Housing, No Grants," Washington Post, June 25, 1977, A16; Ruth Ross, "Introduction: Federal Decentralization and Its Diverse Effects on the Community Development Block Grant," Publius 13, no. 3 (1983): 1-5.

28. Hills v. Gautreaux (425 US 284). Fifteen years after the original case was filed in 1966, Judge John P. Crowley approved an agreement between HUD, the Chicago Housing Authority and the plaintiffs that required CHA to make housing vouchers available to 7,100 Black families over the next decade. More than half the families moved to middle-income suburbs with an average population that was 96 percent white. See Leonard S. Rubinowitz and James E. Rosenbaum, Crossing the Class and Color Lines: From Public Housing to White Suburbia (Chicago: University of Chicago Press, 2000). 
29. “Mrs. Hills Says Suburbs Will See Housing Needs," New York Times, April 29, 1976.

30. USCCR, The Federal Civil Rights Enforcement Effort: 1974 (Volume VII: To Preserve, Protect, and Defend the Constitution) (Washington, DC: US Government Printing Office, 1974).

31. Christopher Lydon, "Carter Defends All-White Areas," New York Times, April 7, 1976; Christopher Lydon, "Carter Issues an Apology on 'Ethnic Purity' Phrase," New York Times, April 9, 1976.

32. Quoted in William E. Leuchtenburg, "Jimmy Carter and the Post-New Deal Presidency," in The Carter Presidency: Policy Choices in the Post-New Deal Era, ed. Gary M. Fink and Hugh Davis Graham (Lawrence: University Press of Kansas, 1998), 16.

33. Thomas J. Sugrue, "Carter's Urban Policy Crisis," in Fink and Graham, The Carter Presidency, 137-157; Leuchtenburg, "Jimmy Carter and the Post-New Deal Presidency," 17.

34. By 1980, when the law was up for reauthorization, executives at lending institutions called in vain for it to die, arguing that the HMDA produced unnecessary red tape and that they rarely received requests for the data they were mandated to collect. Gary Washburn, "Redlining Battle Revived by Disclosure Law," Chicago Tribune, June 22, 1980.

35. Sidney, Unfair Housing, 59; John Yinger, Closed Doors, Opportunities Lost: The Continuing Costs of Housing Discrimination (New York: Russell Sage Foundation, 1995), 197.

36. Sidney, Unfair Housing, 42.

37. US Commission on Civil Rights, The Federal Fair Housing Enforcement Effort (Washington, DC: US Government Printing Office, 1979).

38. Ibid., 77. Lenders complained that the laws failed to distinguish between "good" loan denials, in which the prospective borrower had insufficient income, and "bad" denials, in which race was the reason for refusing to grant the loan request. Robert Guenther, "Laws against Redlining Force Lenders to Make Some Shifts," Wall Street Journal, December 29, 1982.

39. "Cities in Peril," U.S. News and World Report, April 7, 1975, 29.

40. Robert D. McFadden, "Abraham Beame Is Dead at 94; Mayor during 70’s Fiscal Crisis," New York Times, February 11, 2001.

41. Frank Van Riper, "Ford to New York: Drop Dead," New York Daily News, October 30, 1975, http://www.nydailynews.com/features/bronxisburning/battle-for-the-city/Ford-to-NewYork-Drop-Dead.html; McFadden, "Abraham Beame Is Dead at 94"; Patterson, Restless Giant.

42. John F. Bauman, "Jimmy Carter, Patricia Roberts Harris, and Housing Policy in the Age of Limits," in From Tenements to the Taylor Homes: In Search of an Urban Housing Policy in Twentieth-Century America, ed. John F. Bauman, Robert Biles, and Kristin M. Szylvian (University Park: Pennsylvania State University Press, 2000), 249.

43. Sugrue, "Carter's Urban Policy Crisis," 140.

44. Dennis Williams (with Christopher Ma), "A Family Squabble," Newsweek, August 8, 1977, 16-18.

45. Warren Brown, "Harris: Turning Doubters into Supporters," Washington Post, July 20, 1979.

46. Ibid.

47. "Transcript of President's News Conference on Foreign and Domestic Matters," New York Times, March 10, 1977.

48. Robert Reinhold, “Mrs. Harris Tackling Urban Problems Cautiously," Washington Post, April 8, 1977. Harris had sharp political differences with Carter-objecting to efforts to convert housing aid into a voucher system and chafing at severe budgetary limits on HUD spendingbut her refusal to air these grievances publicly earned the appreciation of the White House. See Bauman, "Jimmy Carter, Patricia Roberts Harris, and Housing Policy in the Age of Limits."

49. Chapman, "HUD Tying Funds for Communities to Subsidize Housing." HUD was pushed to enforce the low-income housing provision more vigorously in early 1976 after federal courts ruled in favor of Hartford, Connecticut, which sued seven suburban towns and HUD for failing to provide housing for individuals who worked in the communities but lived in Hartford.

50. National Committee against Discrimination in Housing, "The Carter Administration's Urban Policy Options: Equal Opportunity in Metropolitan Mobility vs. An Inner-City Strategy," October 4, 1977, filed in HU 14, 1-4, JC. 
51. Quoted in Lamb, Housing Segregation in Suburban America since 1960, 179.

52. Bauman, "Jimmy Carter, Patricia Roberts Harris, and Housing Policy in the Age of Limits," 260, 261.

53. Robert Reinhold, “H.U.D., in 'Major Policy Change,' Increasing Aid to Central Cities," New York Times, December 28, 1977; "H.U.D. Threatens to Cut Funds If Cities Neglect LowIncome Housing," New York Times, March 8, 1977.

54. Robert Reinhold, "Head of H.U.D. Hears Problems of Mayors," New York Times, June 13, 1977; Reinhold, "H.U.D., in 'Major Policy Change,' Increasing Aid to Central Cities."

55. "Program Standards and Evaluation," 1979, Patricia Roberts Harris Papers, Box 19, Briefing Books: Fair Housing and Equal Opportunity, Management Initiatives 1979, LC.

56. Comptroller General of the United States, "Stronger Federal Enforcement Needed to Uphold Fair Housing Laws" (Washington, DC: Government Printing Office, February 2, 1978); Letters, Chester C. McGuire (HUD Assistant Secretary for Fair Housing and Equal Opportunity) to Henry Eschwege, October 31 and November 7, 1977. These letters are included as Appendices I and II in the Comptroller General's report.

57. Robert Reinhold, "H.U.D. Plans 20th Reorganization," New York Times, October 14, 1977.

58. Herbert H. Denton, "U.S. Moves to Cut Use of Public Housing as Integration Tool," Washington Post, September 28, 1980. Clay's comments also drew upon many African Americans' disappointment with large federal programs that purported to help disadvantaged groups, but failed to live up to their promise, sometimes-as with urban renewal-in terribly destructive fashion. For an insightful discussion on the turn among some African Americans from integration to community control, see Wendell Pritchett, Brownsville, Brooklyn: Blacks, Jews, and the Changing Face of the Ghetto (Chicago: University of Chicago Press, 2002).

59. Graham, "Civil Rights Policy in the Carter Presidency."

60. Lamb, Housing Segregation in Suburban America since 1960.

61. Julie Johnson, "Reagan Signs Bill to Fight Housing Discrimination," New York Times, September 14, 1988; Lamb, Housing Segregation in Suburban America since 1960.

62. Rochelle L. Stanfield, "Fair Housing: Still Doors to Open after 11 Years," National Journal, May 5, 1979, 1-8.

63. Bonastia, Knocking on the Door; Michael H. Schill and Samantha Friedman, "The Fair Housing Amendments Act of 1988: The First Decade," Cityscape 4, no. 3 (1999): 57-78.

64. Seng and Caruso, "Achieving Integration," 56.

65. Seng and Caruso, "Achieving Integration."

66. Lamb, Housing Segregation in Suburban America since 1960; The President's Commission on Housing, Report of the President's Commission on Housing (Washington, DC: US Government Printing Office, 1982).

67. Hays, Federal Government and Urban Housing, 236.

68. US General Accounting Office, Fair Housing: Opportunities to Improve HUD's Oversight and Management of the Enforcement Process (Washington, DC: US Government Printing Office, 2004). See fig. 5, p. 28.

69. Byron York, "HUD Makes Last Try to Keep Itself Alive," Baltimore Sun, December 25, 1994.

70. Jeff Bailey, "Unlikely Activist Gets Chicago Banks to Give Loans to Poor Sections," Wall Street Journal, August 21, 1985.

71. Yinger, Closed Doors, Opportunities Lost.

72. Stanley Ziemba, "Redlining Fight Bearing Fruit in Money-Strapped Inner Cities," Chicago Tribune, May 25, 1986.

73. Bailey, "Unlikely Activist Gets Chicago Banks to Give Loans to Poor Sections."

74. Nicholas D. Kristof, "Congress Redraws Plan on Housing Grants," Washington Post, August 24, 1981.

75. Lamb, Housing Segregation in Suburban America since 1960.

76. Jason DeParle, "Housing Secretary Carves Out Role as a Lonely Clarion against Racism," New York Times, July 8, 1993. 
77. Susan J. Popkin, George C. Galster, Kenneth Temkin, Carla Herbig, Diane K. Levy, and Elise K. Richer, "Obstacles to Desegregating Public Housing: Lessons Learned from Implementing Eight Consent Decrees," Journal of Policy Analysis and Management 22, no. 2 (2003): 182.

78. John Goering and Judith D. Feins, eds., Choosing a Better Life? Evaluating the Moving to Opportunity Social Experiment (Washington, DC: Urban Institute Press, 2003); Lamb, Housing Segregation in Suburban America since 1960. On the mixed results of Moving to Opportunity, see Xavier de Souza Briggs, Susan J. Popkin and John Goering, Moving to Opportunity: The Story of an American Experiment to Fight Ghetto Poverty (New York: Oxford University Press, 2010).

79. For the goals of the 1997 Strategic Plan, see Florence Wagman Roisman, "Long Overdue: Desegregation Litigation and Next Steps to End Discrimination and Segregation in the Public Housing and Section 8 Existing Housing Programs," Cityscape 4, no. 3 (1999): 184n57; US Department of Housing and Urban Development, "HUD Strategic Plan, FY 2006-FY 2011," March 31, 2006, http://nhl.gov/offices/cfo/reports/hud_strat_plan_2006-2011.pdf.

80. Margery Austin Turner and G. Thomas Kingsley, Federal Programs for Addressing Low-Income Housing Needs (Washington, DC: Urban Institute, 2008), 5, http://www.urban. org/UploadedPDF/411798_low-income_housing.pdf.

81. Turner and Kingsley, Federal Programs for Addressing Low-Income Housing Needs.

82. To have substantial effects on economic and racial segregation, housing-assistance programs would likely require substantial expansion. Deep-subsidy federally assisted housingprogram recipients must have incomes below 80 percent of local area median; less than onequarter of eligible households receive assistance.

83. Sidney, Unfair Housing.

84. Vesla M. Weaver, "Frontlash: Race and the Development of Punitive Crime Policy," Studies in American Political Development 21 (Fall 2007): 247.

85. Ibid., 230, 258.

86. Ibid.

87. On these early attacks on government bureaucrats, see Dan T. Carter, The Politics of Rage: George Wallace, the Origins of the New Conservatism, and the Transformation of American Politics (New York: Simon and Schuster, 2000), 425; "Critics of Bureaucrats: Nixon and Wallace," National Journal, December 16, 1972, 1935. In 1965, three-quarters of Americans trusted the government in Washington "to do what is right" "most of the time" or "just about always." That proportion declined to 53 percent in 1973, and 25 percent in 1981. See Virginia A. Chanley, "Trust in Government in the Aftermath of 9/11: Determinants and Consequences," Political Psychology 23, no. 3 (2002): 469-483.

88. On ties between "the racial politics of crime" and "the racial politics of antiwelfarism," see also Ian F. Haney Lopez, "Post-Racial Racism: Racial Stratification and Mass Incarceration in the Age of Obama," California Law Review 98, no. 3 (2010): 1023-1073.

89. Lamb, Housing Segregation in Suburban America since 1960.

90. See Bonastia, Knocking on the Door.

91. Chapman, "HUD Tying Funds for Communities to Subsidize Housing."

92. For overviews, see Bonastia, Knocking on the Door; Massey and Denton, American Apartheid.

93. Weaver, "Frontlash."

94. Shanna L. Smith, Testimony before the House Judiciary Committee Subcommittee on the Constitution, Civil Rights, and Civil Liberties, March 11, 2010, http://judiciary.house. gov/hearings/pdf/Smith100311.pdf. See also Bonastia, Knocking on the Door; Leadership Conference on Civil Rights, The Future of Fair Housing: Report of the National Commission on Fair Housing and Equal Opportunity, 2008, http://www.civilrights.org/publications/reports/ fairhousing/. 